\title{
The Role of Work/Life Balance and Motivational Drivers of Employee Engagement on the Relationship between Talent Management and Organization Performance: A Developing Country Perspective
}

\author{
Ala'aldin Alrowwad ${ }^{1}$, Bader Obeidat ${ }^{2}$, Areej Al-Khateeb ${ }^{2} \&$ Ra'ed Masa'deh $^{3}$ \\ ${ }^{1}$ Department of Business Management, School of Business, The University of Jordan, Aqaba Branch, Jordan \\ ${ }^{2}$ Department of Business Management, School of Business, The University of Jordan, Amman, Jordan \\ ${ }^{3}$ Department of Management Information Systems, School of Business, The University of Jordan, Amman, Jordan \\ Correspondence: Ala'aldin Alrowwad, Department of Business Management, School of Business, The University \\ of Jordan, Aqaba Branch, Jordan. E-mail: a.alrowwad@ju.edu.jo
}

Received: March 10, 2018 Accepted: September 20, $2018 \quad$ Online Published: October 29, 2018

doi:10.5539/mas.v12n11p35 URL: https://doi.org/10.5539/mas.v12n11p35

\begin{abstract}
The purpose of this paper is to explore the relationship between talent management, work life balance, motivational drivers of employee engagement and organization performance in telecommunication and information technology sector in Jordan. Both work life balance and motivational drivers of employee engagement were examined as mediators between talent management and organization performance. The population of the study consists of the three main telecommunication operators in Jordan; Zain, Orange and Umniah with a total number of employees (3305), a random sample appointed from the population with a total 250 questionnaires filled up. The study found a positive relationship between talent management and its three dimensions, namely talent attraction, talent development and talent retention with organization performance. Results also found a positive relationship between talent management and its three dimensions with work life balance. A positive relationship also found between talent management and its dimensions with motivational drivers of employee engagement. Finally, work life balance found to partially mediating the relationship between talent management and organization performance and motivational drivers of employee engagement fully mediating this relationship between talent management and organization performance. This study stated many recommendations for future researches.
\end{abstract}

Keywords: corporate social responsibility, transformational leadership, firm performance, IT employees, Jordanian banks

\section{Introduction}

Dynamic and complex environment expand the competition since 1980s to go broader than competing over market share, customers, financial resources and technology to compete over acquisition, developing and retaining talent employees. Those talents are considered to be a major source of organization uniqueness and differentiation. Although from 1990s different term of talent management had captured the interest of researchers and managers (Bat \& Yalçın, 2015), there is still a shortage of it, especially in developing countries where Jordan is part of. The stimulation of this study emerges from the fact that talent management researches are in shortage in Arab countries generally and in Jordan specifically. Few researchers have studied the relationship between talent management and organization performance in Jordanian telecommunication and information technology sector. Talent management importance is highlighted in the service sector, where there is no standard way to get the job done, timeliness and professionalism are distinguishing one firm from another (Canavan, et al., 2013; Masa'deh et al., 2015). The telecommunication and information technology sector is an initial part of the service sector; it is growing rapidly all over the world and precisely in developing countries. "Some estimates predict that developing countries constitute about 67 percent of the worldwide mobile subscriptions" (Shafei \& Tabaa, 2016, page: 2).

Telecommunication and information technology sector in Jordan is facing many challenges. One challenge is the threat of being just a data provider and reduces the traditional profit from short message service and voice call because of the widespread of internet communication tools such as Skype, Viber \& Whatsapp, since people are 
looking for substitute product and services that fulfill their need with lower cost. People intention to find lower cost alternative products are due to the limitations of consumption that arise when their consumption ability is restricted by a fixed amount of disposable income and/or leisure time to be spent. Therefore, Jordanian telecommunication and information technology sector is highly competitive and can be considered as the most competitive in the Middle East (Alnsour et al., 2014; Hajir et al., 2015). The second challenge is the shortage of trained employees that have needed skills. This challenge is a due to two reasons, the first one is the fact that the Jordanian labor market is losing trained and experienced employees to the favor of other Arab countries, especially the Gulf ones. The second one is the fact that newly graduated students are not qualified to substitute the lost ones and they must train for one year and sometimes more.

Furthermore, work life balance programs and practices were emerged in the 1970s in an attempt to minimize the conflict between employees' work responsibilities and life responsibilities, focusing on employees' roles in society such as a parent, sons and friends. Akanji \& associates (2015) defined the main dilemmas that make it harder for employees to equalize between their work life and non-work life and raise the importance to have work life balance practices; longer working hours, global economic crises, parents who are working in two or more jobs and growth of women percentage within the workforce. Although studies of work life balance are increasing, but still in shortage, especially in developing countries where a survey conducted in 2007 estimated that $75 \%$ of work and life balance studies focus on employees in USA (Casper et al., 2007). Although, employee engagement is an important source of competitive advantage, but still research and focuses on talent engagement strategies are in shortage in Jordan and precisely in telecommunication and information technology sector. This paper is organized as follows: the first section sets the context of the need to study the influence of talent management on organization performance. The next section examines the research conceptual framework and hypotheses. The next section indicates the research methodology, and the final section provides the research findings and conclusions.

\section{Research Framework and Hypotheses}

This research was conducted to study the relationship between talent management and organization performance defined by human resources and motivation. It also examines the role of motivational drivers of employee engagement and work life balance practices to support and smooth this relationship between talent management and organization performance in the telecommunication and information technology sector Jordan, where this sector is highly important and competitive.

\subsection{Operational Definitions}

Dependent, independent and mediating variables of the study are operationalized as follows.

Talent management: is the process of attracting, developing and retaining qualified employees to satisfy organizations' needs (Mathew, 2015).

Talent attraction: is the process of looking up externally to attract the right people to fill the right job in an organization according to the organization specific needs (Garavan et al., 2012).

Talent development: it is about having a career path of development for employees that help organizations face their uncertain and ambiguous environment. This career path is built through the development of a hyper talent pool that is always ready to supply knowledgeable and skilled employees in constant with organization goals and objectives (Slavković et al., 2015).

Talent retention: is the company efforts to market and sustain a good image of itself to avoid losing its internal employees, especially the key and valuable ones (Bhatnagar, 2007).

Work/life balance: is an organization internal social responsibility toward their employees, where organization gives employees the opportunity to equilibrate between their work and non-work life responsibilities and harmonize their life aspects (Gołaszewska-Kaczan, 2015), work life balance represents the first mediating variable; it concentrates the influence of the independent variable on the dependent variable either on negative or positive way. Employment and working hours: it is about having a flexible work arrangement for employees such as giving them the freedom to carry out their job remotely outside the office when it's necessary to their non-working commitments (Gołaszewska-Kaczan, 2015).

Family care: Support employees to take care of their family members, especially those who are disabled, elder and newborn family members (Helmle et al., 2014).

Organizational culture reinforcement: is about having an internal environment associated with management practices that enhance work life balance practices. An organization is considered to be a work life balance supporters not by having work life balance practices written in their manuals, but by having a culture that 
encourages the spread of those practices and not judging or evaluating employees negatively for taking advantage of them (Idrovo et al., 2012).

Fringe benefit: is about organizations that try to facilitate some of their employees needs from the outside society by offering those discounts in restaurants, access to gyms, and insurance coverage for them and their family members (Helmle et al., 2014).

Motivational drivers of employee engagement: they are the drivers that boost employees' positive feelings toward their organization which stimulates their beliefs, commitment, motivation and loyalty. Motivational drivers of employee engagement lead to favorable working attitudes (Bhuvanaiah \& Raya, 2015). Motivational drivers of employee engagement represent the second mediating variable in the study. They were measured using four concepts as mentioned by Bhuvanaiah \& Raya (2015); decision making authority, opportunities for growth and development, fair treatment and leadership.

Decision making authority: it is about listening to the voice of employees and giving them the opportunity to challenge themselves in deciding what tasks to handle and what results to give (Bhuvanaiah \& Raya, 2015). Appreciating their decisions in dilemmas time and let them feel free in representing their ideas.

Opportunities for growth and development: it is the upper management and employees' direct manager concern to train their employees and provide them the knowledge and skills they need to develop, it is about having a future plan for employees (Robinson et al., 2004).

Fair treatment: Employees are looking for recognition that matches their efforts to feel fairness (Coff \& Kryscynski, 2011). An important part of this fair treatment is the disclosure and the announcement from the organization of their reasons and methods behind the internal decision of performance appraisal, promotions, bounces, compensation and salaries raising (Thunnissen, 2016).

Leadership: managers' relationship with their followers to motivate and inspire them. Leadership is about how mentally and emotionally managers can influence their subordinates to feel independent and admired while they are carrying out their tasks (Gözükara \& Şimşek, 2015).

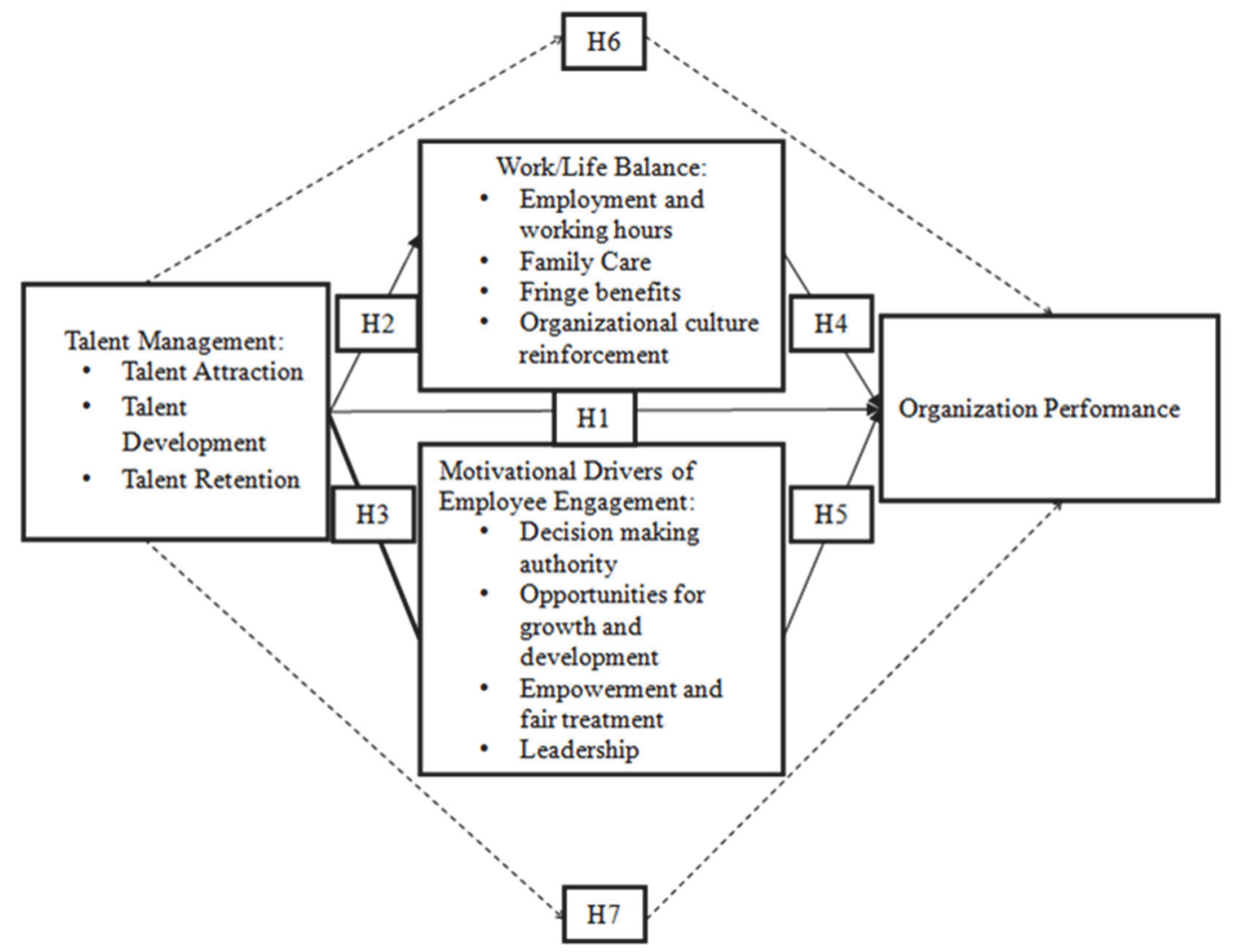

Figure 1. The proposed research model

Organization performance: it is organization end state results divided into three types of outcomes; human 
resources outcomes, operational outcomes and financial outcomes (Jiang et al., 2012). Human resource outcomes represent many areas related to employees, for example their satisfaction, commitment, motivation and how efficiently an organization utilizes their competences. Moreover, operational outcomes are related to the quality of organizations' processes and procedures such as their efficiency, productivity and effectiveness. Finally, financial results are mainly interested in the sales ratios, market share, expansion ratios and many others (Slavković et al., 2015).

Human resources: are employees' capabilities, skills and abilities that play a significant role in organizations success (Jiang et al., 2012). Human resources is the result of implementing proper human resources procedures which view organizations' human resources as an asset rather than a cost (Pickett, 2015).

Motivation: it is about stimulating people and encouraging them to perform their work efficiently and effectively. Motivation can be defined as a conditional effort from employees to accomplish organization goals and objectives with believing of some individual gaining and achieving some personal needs (Johnson, 2004).

Research theoretical model is illustrated in figure (1) which clarifies the relationship between study variables.

This study has seven main hypotheses to examine the mediating role of motivational drivers of employee engagement and work/life balance on the relationship between talent management and Organization Performance.

First Main Hypothesis:

Ho1: There is no significant relationship at $(\alpha \leq 0.05)$ between talent management and organization performance.

Sub Hypotheses Derived from the First Main Hypothesis:

Ho.1.1: There is no significant relationship at $(\alpha \leq 0.05)$ between talent attraction and organization performance.

Ho.1.2: There is no significant relationship at $(\alpha \leq 0.05)$ between talent development and organization performance.

Ho.1.3: There is no significant relationship at $(\alpha \leq 0.05)$ between talent retention and organization performance. Second Main Hypothesis:

Ho2: There is no significant relationship at $(\alpha \leq 0.05)$ between talent management and work/life balance.

Sub Hypotheses Derived from the Second Main Hypothesis:

Ho.2.1: There is no significant relationship at $(\alpha \leq 0.05)$ between talent attraction and work/life balance.

Ho.2.2: There is no significant relationship at $(\alpha \leq 0.05)$ between talent development and work/life balance.

Ho.2.3: There is no significant relationship at $(\alpha \leq 0.05)$ between talent retention and work/life balance.

Third Main Hypothesis:

Ho3: There is no significant relationship at $(\alpha \leq 0.05)$ between talent management and motivational drivers of employee engagement.

Sub Hypotheses Derived from the Third Main Hypothesis:

Ho3.1: There is no significant relationship at $(\alpha \leq 0.05)$ between talent attraction and motivational drivers of employee engagement.

Ho3.2: There is no significant relationship at $(\alpha \leq 0.05)$ between talent development and motivational drivers of employee engagement.

Ho3.3: There is no significant relationship at $(\alpha \leq 0.05)$ between talent retention and motivational drivers of employee engagement.

Fourth Main Hypothesis:

Ho4: There is no significant relationship at $(\alpha \leq 0.05)$ between work/life balance and organization performance.

Sub Hypotheses Derived from the Fourth Main Hypothesis:

Ho4.1: There is no significant relationship at $(\alpha \leq 0.05)$ between employment and working hours on organization performance.

Ho4.2: There is no significant relationship at $(\alpha \leq 0.05)$ between family care and organization performance.

Ho4.3: There is no significant relationship at $(\alpha \leq 0.05)$ between fringe benefits and organization performance.

Ho4.4: There is no significant relationship at $(\alpha \leq 0.05)$ between organizational culture reinforcement and organization performance. 
Fifth Main Hypothesis:

Ho5: There is no significant relationship at $(\alpha \leq 0.05)$ between motivational drivers of employee engagement and organization performance.

Sub Hypotheses Derived from the Fourth Main Hypothesis:

Ho5.1: There is no significant relationship at $(\alpha \leq 0.05)$ between decision making authority and organization performance.

Ho5.2: There is no significant relationship at $(\alpha \leq 0.05)$ between opportunities for growth and development and organization performance.

Ho5.3: There is no significant relationship at $(\alpha \leq 0.05)$ between empowerment and fair treatment and organization performance.

Ho5.4: There is no significant relationship at $(\alpha \leq 0.05)$ between leadership and organization performance.

\section{Sixth Main Hypothesis:}

Ho6: There is no mediating role of work/life balance on the relationship between talent management and organization performance.

Seventh Main Hypothesis:

Ho7: There is no mediating role of motivational drivers of employee engagement on the relationship between talent management and organization performance.

\subsection{Population and Sample of the Study}

This research is conducted in the city of Amman (the Capital of the Hashemite Kingdom of Jordan). The three telecommunication operators; Zain, Umnieh and Orange represent the research population and they are targeted. Population of this study consists of all the employees working in the three leading companies in the telecommunication and information technology sector in Jordan; Zain, Orange and Umniah. Table (1) represents the number of employees at each company as illustrated in the official website for each one as follows:

Table 1. Number of employees working in Zain, Orange and Umniah at the end of 2015

\begin{tabular}{lll}
\hline Company & Total number of employees & Total percentage of number of employees (\%) \\
\hline Zain & 1000 & $30 \%$ \\
Orange & 1805 & $55 \%$ \\
Umniah & 500 & $15 \%$ \\
Total & 3305 & $100 \%$ \\
\hline
\end{tabular}

After that, a random sample that represents the three organizations' employees is targeted, since targeting the whole population is not an easy task and has difficulties on the researchers of time, cost and other human resources issues. So over, the data are collected through random sampling from the population within the three telecommunication operators and the unit of analysis is all levels of employees. As defined by Sekaran and Bougie (2013) the sample size for a population composed of 3305 employees must be 345 employees.

\subsection{Data Collection Methods}

A secondary data collection in this research is carried out through searching books, journal articles, and other research papers about the subject needed to build the existing research on. Also, primary data are gathered through a personally administrative questionnaire.

\subsection{Validity and Reliability}

Face validity is a feasibility study where the researcher is trying to pre-determine and early judge how effective and acceptable are the research data collection instrument; thus, this research adopts a pilot study technique to measure the face validity of the questionnaire; it was distributed to 25 participants from the study population. The result of the pilot study was initially valid and was acceptable to go further and distribute the questionnaire for the actual sample. In addition, Cronbach's alpha was used to measure the scale reliability, thus it measures the internal consistency and stability of the measure (the questionnaire) and how closely its items related to each other's. The accepted as given by Pallant (2005, p. 7) "Ideally, the Cronbach alpha coefficient of a scale should be above 0.60". 
Table 2. Cronbach's alpha coefficients

\begin{tabular}{lll}
\hline Study construct & Number of items & Cronbach's alpha values \\
\hline Talent attraction & 5 & 0.866 \\
Talent development & 5 & 0.877 \\
Talent retention & 4 & 0.887 \\
Talent management & 14 & 0.944 \\
Employment and working hours & 4 & 0.831 \\
Family care & 4 & 0.796 \\
Organizational culture reinforcement & 4 & 0.712 \\
Fringe benefits & 5 & 0.750 \\
Work life balance & 17 & 0.806 \\
Decision making authority & 5 & 0.911 \\
Opportunities for growth and development & 3 & 0.805 \\
Fair treatment & 4 & 0.825 \\
Leadership & 4 & 0.894 \\
Motivational drivers of employee engagement & 16 & 0.948 \\
Human capital & 5 & 0.916 \\
Motivation & 5 & 0.860 \\
Organization performance & 10 & 0.899 \\
All & 57 & 0.962 \\
\hline
\end{tabular}

It can be seen from the table above that all values are greater than 0.70 which is a good indicator because it is greater than the accepted percent 0.60 (Pallant, 2005). The internal consistency reliability was very good and acceptable and can be considered to be reliable to achieve the research objectives.

\section{Research Results}

\subsection{Correlation Analysis}

In order to examine the study hypothesis, the research conducted both correlation and inferential statistics in this part. Accordingly, the correlation analysis will be conducted firstly as below:

\subsubsection{First Main Hypothesis}

It is clearly evident from the table (3) that the independent variables under the main and sub first hypotheses have a significant relationship with organization performance. Furthermore, it can be seen from the table above that talent management has the highest correlation with organizational performance with $r=0.651$ and it is significant at 0.01 .

Table 3. Correlation analysis for the main and sub first hypotheses

\begin{tabular}{cccccc}
\hline & $\begin{array}{c}\text { Organization } \\
\text { performance }\end{array}$ & $\begin{array}{c}\text { Talent } \\
\text { management }\end{array}$ & $\begin{array}{c}\text { Talent } \\
\text { attraction }\end{array}$ & $\begin{array}{c}\text { Talent } \\
\text { development }\end{array}$ & $\begin{array}{c}\text { Talent } \\
\text { retention }\end{array}$ \\
\hline Organization & 1 & & & & \\
performance & & & & & \\
Talent management & $.651^{* *}$ & 1 & & & \\
Talent attraction & $.648^{* *}$ & $.896^{* *}$ & 1 & & \\
Talent development & $.608^{* *}$ & $.940^{* *}$ & $.776^{* *}$ & 1 & 1 \\
Talent retention & $.548^{* *}$ & $.926^{* *}$ & $.714^{* *}$ & $.825^{* *}$ & 1 \\
\hline
\end{tabular}

**. Correlation is significant at the 0.01 level (2-tailed).

As a consequence, to support judging the first main and sub hypotheses, the inferential statistics will be conducted below: 
Table 4. Multiple regression analysis for the main and sub first hypotheses

\begin{tabular}{|c|c|c|c|c|c|c|c|c|}
\hline \multirow[t]{3}{*}{ Variables } & \multicolumn{3}{|c|}{ Model summary } & \multicolumn{2}{|c|}{ ANOVA } & \multicolumn{2}{|c|}{ Coefficients(a) } & \multirow{2}{*}{$\begin{array}{c}\begin{array}{c}\text { Unstandardize } \\
\text { d coefficients }\end{array} \\
\text { Beta }\end{array}$} \\
\hline & $\mathrm{R}$ & $\begin{array}{c}\mathrm{R} \\
\text { square }\end{array}$ & $\begin{array}{l}\text { Adjusted R } \\
\text { square }\end{array}$ & $\begin{array}{c}\text { F- } \\
\text { value }\end{array}$ & Sig & $\mathrm{T}$ & $\begin{array}{l}\text { Sig.(P- } \\
\text { value) }\end{array}$ & \\
\hline & $\begin{array}{c}.66 \\
9\end{array}$ & .448 & .441 & 66.592 & $\begin{array}{c}0.00 \\
0\end{array}$ & & & \\
\hline Constant & & & & & & $\begin{array}{c}10.55 \\
9\end{array}$ & 0.000 & 1.659 \\
\hline Talent attraction & & & & & & 5.672 & 0.000 & 0.366 \\
\hline $\begin{array}{c}\text { Talent } \\
\text { development }\end{array}$ & & & & & & 2.446 & 0.015 & 0.196 \\
\hline Talent retention & & & & & & 0.525 & 0.600 & 0.034 \\
\hline
\end{tabular}

The dependent variable is organizational performance

It can be seen from the result in table (4) that the multiple correlation coefficient $\mathrm{R}=0.669$ indicates that there is a strong positive correlation between talent management and organization performance practices. Also, the value of $\mathrm{R}^{2}=0.448$. This means that the talent management can account 0.448 of the variation of the organization performance. Furthermore, it is noticed that the value of adjusted $R^{2}$ is very close to the value of $R^{2}$. Also, the table above shows the probability of F-value and it is significant at 0.05 , which indicates that talent management has a significant effect on organization performance at $(\alpha \leq 0.05)$.

Referring to the first sub hypothesis under Ho1; the sig-value of talent attraction is 0.000 and it is significant at ( $\alpha$ $\leq 0.05$ ) and the t-calculated is 5.672 and it is higher than the t-tabulated 1.96. Also, the impact value of talent attraction is 0.366 this means that if talent attraction increases by one unit, and then organization performance will increase by 0.366 . This indicates that the talent attraction has a significant effect on the organization performance at $(\alpha \leq 0.05)$. Referring to the second sub hypothesis under Ho1; the sig-value of talent development is 0.015 and it is significant at $(\alpha \leq 0.05)$ and the t-calculated is 2.446 and it is higher than the $t$-tabulated 1.96. Also, the impact value of talent development is 0.196 this means that if talent development increases by one unit, and then organization performance will increase by 0.196 . This indicates that the talent development has a significant effect on the organization performance at $(\alpha \leq 0.05)$.

Referring to the third sub hypothesis under talent management; the sig-value of talent retention is 0.600 and it is insignificant at $(\alpha \leq 0.05)$ and the t-calculated is 0.525 and it is lower than the t-tabulated 1.96. This indicates that the talent retention has no significant effect on the organization performance at $(\alpha \leq 0.05)$. As shown in table (4) in the correlation analysis, there is a relationship between talent retention and organization performance. However, we cannot say if the talent retention increases by one unit, the organization performance will be increased by 0.034 , because the talent retention has no significant effect on the organization performance; in other words the talent retention cannot estimate the value of increases in the organization performance in the future. Therefore, the first main and sub hypotheses are rejected and the alternatives are accepted.

\subsubsection{Second Main Hypothesis}

It is clearly evident from the above table (5) that the independent variables under the main and sub second hypotheses have a significant relationship with work life balance. Furthermore, it can be seen from the table that talent attraction has the highest correlation with work life balance with $r=0.522$ and it is significant at 0.01 . However, talent development experienced the lowest correlation with work life balance with $r=0.468$ and it is significant at 0.01 .

Table 5. Correlation analysis for the main and sub second hypotheses

\begin{tabular}{|c|c|c|c|c|c|}
\hline \multicolumn{6}{|c|}{ Correlations } \\
\hline & $\begin{array}{ll}\text { Work } & \text { life } \\
\text { balance } & \\
\end{array}$ & $\begin{array}{l}\text { Talent } \\
\text { management }\end{array}$ & $\begin{array}{l}\text { Talent } \\
\text { attraction }\end{array}$ & $\begin{array}{l}\text { Talent } \\
\text { development }\end{array}$ & $\begin{array}{l}\text { Talent } \\
\text { retention }\end{array}$ \\
\hline Work life balance & 1 & & & & \\
\hline $\begin{array}{l}\text { Talent } \\
\text { management }\end{array}$ & $.544 * *$ & 1 & & & \\
\hline Talent attraction & $.522 * *$ & $.896 * *$ & 1 & & \\
\hline
\end{tabular}




\begin{tabular}{|c|c|c|c|c|c|}
\hline $\begin{array}{l}\text { Talent } \\
\text { development }\end{array}$ & $.468 * *$ & $.940 * *$ & $.776^{* *}$ & 1 & \\
\hline Talent retention & $.511 * *$ & $.926 * *$ & $.714 * *$ & $.825 * *$ & 1 \\
\hline
\end{tabular}

**. Correlation is significant at the 0.01 level (2-tailed).

As a consequence, to support judging the second main and sub hypotheses, the inferential statistics will be conducted below:

Table 6. Multiple regression analysis for the main and sub second hypotheses

\begin{tabular}{|c|c|c|c|c|c|c|c|c|}
\hline \multirow[t]{4}{*}{ Variables } & \multicolumn{3}{|c|}{ Model summary } & \multicolumn{2}{|c|}{ ANOVA } & \multicolumn{2}{|c|}{ Coefficients(a) } & $\begin{array}{l}\text { Unstandardize } \\
\text { d coefficients }\end{array}$ \\
\hline & $\mathrm{R}$ & $\begin{array}{c}\mathrm{R} \\
\text { square }\end{array}$ & $\begin{array}{l}\text { Adjusted R } \\
\text { square }\end{array}$ & $\begin{array}{c}\text { F- } \\
\text { value }\end{array}$ & Sig & $\mathrm{t}$ & $\begin{array}{l}\text { Sig.(P- } \\
\text { value) }\end{array}$ & Beta \\
\hline & 0.55 & 0.312 & 0.304 & 37.170 & 0.00 & & & \\
\hline & 8 & & & & 0 & & & \\
\hline \multirow[t]{2}{*}{ Constant } & & & & & & 12.10 & 0.000 & 1.745 \\
\hline & & & & & & 6 & & \\
\hline Talent attraction & & & & & & 3.978 & 0.000 & 0.235 \\
\hline Talent & & & & & & -0.507 & 0.612 & -0.037 \\
\hline development & & & & & & & & \\
\hline Talent retention & & & & & & 3.261 & 0.001 & 0.191 \\
\hline
\end{tabular}

The dependent variable is work life balance

It can be seen from the result in table (6) that the multiple correlation coefficient $\mathrm{R}=0.558$ indicates that there is a strong positive correlation between talent management and work life balance practices. Also, the value of $\mathrm{R}^{2}=0.312$. This means that the talent management can account 0.312 of the variation of the work life balance. Also, the table above shows the probability of F-value and it is significant at 0.05 , which indicates that talent management has a significant effect on work life balance at $(\alpha \leq 0.05)$. Referring to the first sub hypothesis under Ho2; the sig-value of talent attraction is 0.000 and it is significant at $(\alpha \leq 0.05)$ and the $t$-calculated is 3.978 and it is higher than the t-tabulated 1.96. Also, the impact value of talent attraction is 0.235 this mean that if talent attraction increases by one unit, then work life balance will increase by 0.235 . This indicates that the talent attraction has a significant effect on the work life balance at $(\alpha \leq 0.05)$. Referring to the second sub hypothesis under Ho2; the sig-value of talent development is 0.612 and it is insignificant at $(\alpha \leq 0.05)$ and the t-calculated is $(-0.507)$ and it is lower than the t-tabulated 1.96. This indicates that the talent development has no significant effect on the organization performance at $(\alpha \leq 0.05)$. However, as shown in table $(6)$ in the correlation analysis, there is a relationship between talent development and work life balance. Therefore, we can say that talent development has a significant relationship with work life balance and the value of the correlation is 0.468 and it is significant at 0.01 . However, we cannot say if the talent development decreases by one unit, the work life balance will be decreased by 0.037 , because the talent development has no significant effect on the work life balance; in other words the talent development cannot estimate the value of decreases in the work life balance in the future. Referring to the third sub hypothesis under Ho2; the sig-value of talent retention is 0.001 and it is significant at ( $\alpha$ $\leq 0.05$ ) and the t-calculated is 3.261 and it is higher than the t-tabulated 1.96. Also, the impact value of talent retention is 0.191 this mean that if talent development increases by one unit, then work life balance will increase by 0.191 . This indicates that the talent retention has a significant effect on the work life balance at $(\alpha \leq 0.05)$. Therefore, the second main and sub hypotheses are rejected and the alternatives are accepted.

\subsubsection{Third Main Hypothesis}

It is clearly evident from table (7) that the independent variables under the main and sub third hypotheses have a significant relationship with Motivational Drivers of employee engagement. 
Table 7. Correlation analysis for the main and sub third hypotheses

\begin{tabular}{|c|c|c|c|c|c|}
\hline & \multicolumn{4}{|c|}{ Correlations } & \multirow[b]{2}{*}{$\begin{array}{l}\text { Talent } \\
\text { retention }\end{array}$} \\
\hline & $\begin{array}{l}\text { Motivational drivers of } \\
\text { employee engagement }\end{array}$ & $\begin{array}{l}\text { Talent } \\
\text { management }\end{array}$ & $\begin{array}{l}\text { Talent } \\
\text { attraction }\end{array}$ & $\begin{array}{l}\text { Talent } \\
\text { development }\end{array}$ & \\
\hline $\begin{array}{l}\text { Motivational drivers } \\
\text { employee engagement }\end{array}$ & 1 & & & & \\
\hline Talent management & $.745 * *$ & 1 & & & \\
\hline Talent attraction & $.655 * *$ & $.896^{* *}$ & 1 & & \\
\hline Talent development & $.693 * *$ & $.940 * *$ & $.776^{* *}$ & 1 & \\
\hline Talent retention & $.708 * *$ & $.926^{* *}$ & $.714 * *$ & $.825 * *$ & 1 \\
\hline
\end{tabular}

**. Correlation is significant at the 0.01 level (2-tailed).

As a consequence, to support judging the third main and sub hypotheses, the inferential statistics will be conducted below:

Table 8. Multiple regression analysis for the main and sub third hypotheses

\begin{tabular}{|c|c|c|c|c|c|c|c|c|c|}
\hline \multirow[t]{4}{*}{ Variables } & \multicolumn{4}{|c|}{ Model summary } & \multicolumn{2}{|c|}{ ANOVA } & \multicolumn{2}{|c|}{ Coefficients(a) } & \multirow{2}{*}{$\begin{array}{l}\text { Unstandardize } \\
\text { d coefficients } \\
\text { Beta }\end{array}$} \\
\hline & $\mathrm{R}$ & $\begin{array}{l}\mathrm{R} \\
\text { Square } \\
\end{array}$ & $\begin{array}{l}\text { Adjusted } \\
\text { Square }\end{array}$ & $\mathrm{R}$ & $\begin{array}{l}\text { F- } \\
\text { value }\end{array}$ & Sig & $\mathrm{t}$ & $\begin{array}{l}\text { Sig.(P- } \\
\text { value) }\end{array}$ & \\
\hline & 0.74 & 0.558 & 0.552 & & 103.44 & 0.00 & & & \\
\hline & 7 & & & & 3 & 0 & & & \\
\hline \multirow[t]{2}{*}{ Constant } & & & & & & & 4.48 & 0.000 & 0.733 \\
\hline & & & & & & & 7 & & \\
\hline \multirow[t]{2}{*}{ Talent attraction } & & & & & & & 3.30 & 0.001 & 0.221 \\
\hline & & & & & & & 1 & & \\
\hline Talent & & & & & & & 2.42 & 0.016 & 0.202 \\
\hline development & & & & & & & 1 & & \\
\hline \multirow[t]{2}{*}{ Talent attraction } & & & & & & & 4.90 & 0.000 & 0.326 \\
\hline & & & & & & & 6 & & \\
\hline
\end{tabular}

The dependent variable is motivational drivers of employee engagement

It can be seen from the result in table (8) that the multiple correlation coefficient $\mathrm{R}=0.747$ indicates that there is a strong positive correlation between talent management and motivational drivers of employee engagement practices. Also, the value of $\mathrm{R}^{2}=0.558$. This means that the talent management can account 0.558 of the variation of the motivational drivers of employee engagement. Also, the table above shows the probability of F-value and it is significant at 0.05 , which indicates that talent management has a significant effect on organization performance at $(\alpha \leq 0.05)$.

Referring to the first sub hypothesis under Ho3; the sig-value of talent attraction is 0.001 and it is significant at ( $\alpha$ $\leq 0.05$ ) and the t-calculated is 3.301 and it is higher than the t-tabulated 1.96. Also, the impact value of talent attraction is 0.221 this means that if talent attraction increases by one unit, and then motivational drivers of employee engagement will increase by 0.221 . This indicates that talent attraction has a significant effect on motivational drivers of employee engagement at $(\alpha \leq 0.05)$. Referring to the second sub hypothesis under Ho3; the sig-value of talent development is 0.016 and it is significant at $(\alpha \leq 0.05)$ and the t-calculated is 2.421 and it is higher than the t-tabulated 1.96. Also, the impact value of talent development is 0.202 this means that if talent development increases by one unit, and then motivational drivers of employee engagement will increase by 0.202 . This indicates that talent development has a significant effect on motivational drivers of employee engagement at $(\alpha \leq 0.05)$. Referring to the third sub hypothesis under Ho3; the sig-value of talent retention is 0.000 and it is significant at $(\alpha \leq 0.05)$ and the t-calculated is 4.906 and it is higher than the t-tabulated 1.96. Also, the impact value of talent retention is 0.326 this means that if talent retention increases by one unit, then motivational drivers of employee engagement will increase by 0.326 . This indicates that talent retention has a significant effect on the motivational drivers of employee engagement at $(\alpha \leq 0.05)$. Therefore, the third main and sub hypotheses are rejected and the alternatives are accepted. 


\subsubsection{Fourth Main Hypothesis}

It is clearly evident from table (9) that the independent variables under the main and sub fourth hypotheses have a significant relationship with organization performance.

Table 9. Correlation analysis for the main and sub fourth hypotheses

\begin{tabular}{|c|c|c|c|c|c|c|}
\hline \multicolumn{7}{|c|}{ Correlation } \\
\hline & $\begin{array}{l}\text { Organization } \\
\text { performance }\end{array}$ & $\begin{array}{c}\text { Work life } \\
\text { balance }\end{array}$ & $\begin{array}{l}\text { Employment and } \\
\text { working hours }\end{array}$ & $\begin{array}{l}\text { Famil } \\
\text { y care }\end{array}$ & $\begin{array}{c}\text { Organizational } \\
\text { culture reinforcement }\end{array}$ & $\begin{array}{l}\text { Fringe } \\
\text { benefits }\end{array}$ \\
\hline $\begin{array}{l}\text { Organization } \\
\text { performance }\end{array}$ & 1 & & & & & \\
\hline Work life balance & $.322 * *$ & 1 & & & & \\
\hline $\begin{array}{l}\text { Employment and } \\
\text { working hours }\end{array}$ & $.140^{*}$ & $.742 * *$ & 1 & & & \\
\hline Family care & $.212 * *$ & $.762 * *$ & $.445 * *$ & 1 & & \\
\hline $\begin{array}{c}\text { Organizational } \\
\text { culture reinforcement }\end{array}$ & $.152 *$ & $.649 * *$ & $.340 * *$ & $.382 * *$ & 1 & \\
\hline Fringe benefits & $.386^{* *}$ & $.672 * *$ & $.210 * *$ & $.304 * *$ & $.366 * *$ & 1 \\
\hline
\end{tabular}

**. Correlation is significant at the 0.01 level (2-tailed).

*. Correlation is significant at the 0.05 level (2-tailed).

As a consequence, to support judging the fourth main and sub hypotheses, the inferential statistics will be conducted below:

Table 10. Multiple regression analysis for the main and sub fourth hypotheses

\begin{tabular}{|c|c|c|c|c|c|c|c|c|}
\hline \multirow[t]{4}{*}{ Variables } & \multicolumn{3}{|c|}{ Model summary } & \multicolumn{2}{|c|}{ ANOVA } & \multicolumn{2}{|c|}{ Coefficients(a) } & \multirow{2}{*}{$\begin{array}{l}\text { Unstandardized } \\
\text { coefficients }\end{array}$} \\
\hline & $\mathrm{R}$ & R square & Adjusted & F- & Sig & $\mathrm{T}$ & Sig.(P-value) & \\
\hline & & & R square & value & & & & Beta \\
\hline & 0.400 & 0.160 & 0.146 & 11.650 & 0.000 & & & \\
\hline Constant & & & & & & 10.355 & 0.000 & 2.662 \\
\hline Employment and working hours & & & & & & 0.447 & 0.655 & 0.022 \\
\hline Family care & & & & & & 1.447 & 0.149 & 0.082 \\
\hline Fringe benefits & & & & & & -0.413 & 0.680 & -0.038 \\
\hline $\begin{array}{l}\text { Organizational } \\
\text { reinforcement }\end{array}$ & & & & & & 5.605 & 0.000 & 0.281 \\
\hline
\end{tabular}

The dependent variable is organization performance

It can be noticed from the result in table (10) that the multiple correlation coefficient $\mathrm{R}=0.400$ indicates that there is a positive correlation between work life balance and organization performance practices. Also, the value of $\mathrm{R}^{2}=0.160$. This means that work life balance can account 0.160 of the variation of the organization performance. Also, the table above shows the probability of F-value and it is significant at 0.05 , which indicates that Work Life Balance has a significant effect on Organization Performance at $(\alpha \leq 0.05)$.

Referring to the first sub hypothesis under Ho4; the sig-value of employment and working hours is 0.655 and it is insignificant at $(\alpha \leq 0.05)$ and the t-calculated is 0.447 and it is lower than the t-tabulated 1.96. This indicates that the employment and working hours have no significant effect on the organization performance at $(\alpha \leq 0.05)$. However, as shown in table (10) in the correlation analysis there is a relationship between employment and working hours and organization performance. Therefore, this refers to the fact that the relationship results reflect the type of correlation between the study variables based on the participant responses without taking into account the estimation factors as shown the inferential statistics. Therefore, we can say that employment and working hours have a significant relationship with organization performance and the value of the correlation is 0.140 and it is significant at 0.05 .

Referring to the second sub hypothesis under Ho4; the sig-value of family care is 0.149 and it is insignificant at ( $\alpha$ $\leq 0.05$ ) and the t-calculated is 1.447 and it is lower than the t-tabulated 1.96. This indicates that the family care 
has no significant effect on the organization performance at $(\alpha \leq 0.05)$. However, as shown in table (10) in the correlation analysis, there is a relationship between family care and Organization Performance. Therefore, this refers to the fact that the relationship results reflect the type of correlation between the study variables based on the participant responses without taking into account the estimation factors as shown the inferential statistics. Therefore, we can say that family care has a significant relationship with organization performance and the value of the correlation is 0.212 and it is significant at 0.01 . However, we cannot say if the family care increases with one unit, the organization performance will be increases with 0.082 , because the family care has no significant effect on the organization performance; in other words the family care cannot estimate the value of increases in the organization performance in the future.

Referring to the third sub hypothesis under Ho4; the sig-value of fringe benefits is 0.680 and it is insignificant at $(\alpha \leq 0.05)$ and the t-calculated is $(-0.413)$ and it is lower than the $t$-tabulated 1.96. This indicates that the fringe benefit has no significant effect on the organization performance at $(\alpha \leq 0.05)$. However, as shown in table (10) in the correlation analysis there is a relationship between fringe benefits and organization performance. Therefore, this refers to the fact that the relationship results reflect the type of correlation between the study variables based on the participant responses without taking into account the estimation factors as shown the inferential statistics. Therefore, we can say that fringe benefits have a significant relationship with organization performance and the value of the correlation is 0.386 and it is significant at 0.01 . However, we cannot say if the fringe benefits decrease with one unit, the organization performance will be decreased with 0.038 , because the fringe benefits has no significant effect on the organization performance; in other words the fringe benefits cannot estimate the value of increases in the organization performance in the future.

Referring to the fourth sub hypothesis under Ho4; the sig-value of organizational culture reinforcement is 0.000 and it is significant at $(\alpha \leq 0.05)$ and the $t$-calculated is 5.605 and it is higher than the t-tabulated 1.96. Also, the impact value of organizational culture reinforcement is 0.281 this mean that if organizational culture reinforcement increases by one unit, then organization performance will increase by 0.202 . This indicates that the organizational culture reinforcement has a significant effect on the motivational drivers of employee engagement at $(\alpha \leq 0.05)$. Therefore, the fourth main and sub hypothesis are rejected and the alternatives are accepted.

\subsubsection{Fifth Main Hypothesis}

It is clearly evident from table (11) that the independent variables under the main and sub fifth hypotheses have a significant relationship with organization performance.

Table 11. Correlation analysis for the main and sub fifth hypotheses

\begin{tabular}{|c|c|c|c|c|c|c|}
\hline & $\begin{array}{l}\text { Organization } \\
\text { performance }\end{array}$ & $\begin{array}{l}\text { Motivational drivers of } \\
\text { employee engagement }\end{array}$ & $\begin{array}{l}\text { Decision } \\
\text { making } \\
\text { authority }\end{array}$ & $\begin{array}{l}\text { Opportunities } \\
\text { for growth and } \\
\text { development }\end{array}$ & Fair treatment & Leadership \\
\hline Organization performance & 1 & & & & & \\
\hline $\begin{array}{l}\text { Motivational drivers of } \\
\text { employee engagement }\end{array}$ & $.726^{* *}$ & 1 & & & & \\
\hline Decision making authority & $.651^{* *}$ & $.871 * *$ & 1 & & & \\
\hline $\begin{array}{l}\text { Opportunities for growth } \\
\text { and development }\end{array}$ & $.581 * *$ & $.856^{* *}$ & $.636^{* *}$ & 1 & & \\
\hline Fair treatment & $.672 * *$ & $.927 * *$ & $.751 * *$ & $.734 * *$ & 1 & \\
\hline Leadership & $.662 * *$ & $.877 * *$ & $.676^{* *}$ & $.644 * *$ & $.794 * *$ & 1 \\
\hline
\end{tabular}

**. Correlation is significant at the 0.01 level (2-tailed).

As a consequence, to support judging the fifth main and sub hypotheses, the inferential statistics will be conducted below:

Table 12. Multiple regression analysis for the main and sub fifth hypotheses

\begin{tabular}{|c|c|c|c|c|c|c|c|c|}
\hline \multirow[t]{3}{*}{ Variables } & \multicolumn{3}{|c|}{ Model summary } & \multicolumn{2}{|c|}{ ANOVA } & \multicolumn{2}{|c|}{ Coefficients(a) } & \multirow{2}{*}{$\begin{array}{l}\text { Unstandardized } \\
\text { coefficients }\end{array}$} \\
\hline & $\mathrm{R}$ & $\mathrm{R}$ square & Adjusted R square & F-value & Sig & $\mathrm{T}$ & Sig.(P-value) & \\
\hline & 0.731 & 0.535 & 0.527 & 70.366 & 0.000 & & & Beta \\
\hline Constant & & & & & & 12.314 & 0.000 & 1.659 \\
\hline
\end{tabular}




\begin{tabular}{lrrr}
\hline Decision making authority & 3.867 & 0.000 & 0.193 \\
Opportunities for growth and development & 1.611 & 0.108 & 0.079 \\
Fair treatment & 2.057 & 0.041 \\
Leadership & 3.681 & 0.000 & 0.140 \\
\hline
\end{tabular}

The dependent variable is organization performance

It can be noticed from the result in the table (12) that the multiple correlation coefficient $\mathrm{R}=0.731$ indicates that there is a strong positive correlation between motivational drivers of employee engagement and organization performance practices. Also, the value of $\mathrm{R}^{2}=0.535$. This means that motivational drivers of employee engagement can account 0.535 of the variation of the organization performance. Also, the table above shows the probability of F-value and it is significant at 0.05 , which indicates that motivational drivers of employee engagement have a significant effect on organization performance at $(\alpha \leq 0.05)$.

Referring to the first sub hypothesis under Ho5; the sig-value of decision making authority is 0.000 and it is significant at $(\alpha \leq 0.05)$ and the t-calculated is 3.867 and it is higher than the t-tabulated 1.96. Also, the impact value of decision making authority is 0.193 this means that if decision making authority increases by one unit, then organization performance will increase by 0.193 . This indicates that decision making authority has a significant effect on the organization performance at $(\alpha \leq 0.05)$.

Referring to the second sub hypothesis under Ho5; the sig-value of opportunities for growth development is 0.108 and it is insignificant at $(\alpha \leq 0.05)$ and the t-calculated is 1.611 and it is lower than the t-tabulated 1.96. This indicates that the opportunities for growth and development have no significant effect on the organization performance at $(\alpha \leq 0.05)$. However, as shown in table (12) in the correlation analysis there is a relationship between opportunities for growth and development and organization performance. Therefore, this refers to the fact that the relationship results reflect the type of the correlation between the study variables based on the participant responses without taking into account the estimation factors as shown the inferential statistics. Therefore, we can say that opportunities for growth and development have a significant relationship with organization performance and the value of the correlation is 0.581 and it is significant at 0.01 . However, we cannot say if the opportunities for growth and development increases with one unit, the organization performance will be increases with 0.079 , because the opportunities for growth and development has no significant effect on the organization performance; in other words the opportunities for growth and development cannot estimate the value of increases in the organization performance in the future.

Referring to the third sub hypothesis under Ho5; the sig-value of empowerment and fair treatment is 0.041 and it is significant at $(\alpha \leq 0.05)$ and the t-calculated is 2.057 and it is higher than the t-tabulated 1.96. Also, the impact value of fair treatment is 0.140 this means that if fair treatment increases by one unit, and then organization performance will increase by 0.140 . This indicates that empowerment and fair treatment has a significant effect on the organization performance at $(\alpha \leq 0.05)$.

Referring to the fourth sub hypothesis under Ho5; the sig-value of leadership is 0.000 and it is significant at ( $\alpha \leq$ 0.05 ) and the $\mathrm{t}$-calculated is 3.681 and it is higher than the t-tabulated 1.96. Also, the impact value of leadership is 0.216 this means that if leadership increases by one unit, then organization performance will increase by 0.216 . This indicates that leadership has a significant effect on the organization performance at $(\alpha \leq 0.05)$. Therefore, the fifth main and sub hypotheses are rejected and the alternatives are accepted.

\subsubsection{Sixth Main Hypothesis}

To examine the indirect relationship between talent management and organization performance with existing work life balance as mediating variable; the path analysis of mediation will be used. Accordingly, to examine the role of mediator, the following two steps have been adopted as below:

The first step is to examine the direct impact of talent management on the organization performance in order to show the value of direct impact as well as the sig-value.

Table 13. Direct effect summary

\begin{tabular}{ccccccccccc}
\hline $\begin{array}{c}\text { TM- } \\
\text { OP }\end{array}$ & Chi $^{2}$ & $\begin{array}{c}\text { Chi } \\
2 / \mathrm{df}\end{array}$ & GFI & CFI & $\begin{array}{c}\text { RMSE } \\
\text { A }\end{array}$ & SIG & $\begin{array}{c}\text { DIRECT } \\
\text { IMPACT }\end{array}$ & Sig & C.R & AVE \\
\cline { 2 - 11 } & 18.49 & 4.623 & 0.97 & 0.88 & 0.121 & 0.00 & 0.512 & 0.00 & 8.53 & 0.31 \\
& 4 & & 0 & 6 & & 1 & & 0 & 8 & 4 \\
\hline
\end{tabular}


The results of the direct effect summary and diagram show that the value of direct impact is 0.512 and it is significant at $(\alpha \leq 0.05)$. This implies that the talent management has a significant effect on the organization performance. Additionally, the results in the above reveal that the value of $\mathrm{Chi}^{2}$ is 18.494 and it is significant at $(\alpha \leq 0.05)$. Also, the Minimum Discrepancy value $\left(\mathrm{Chi}^{2} / \mathrm{df}\right)$ is 4.623 which indicate that the harmonization level is good; where (Arbuckle, 2008) stated that the harmonization level range 1 to 5.

Moreover, the Goodness of Fit Index (GFI) which represents the harmonization of quality is 0.970 and this value is close to one (full compatibility). In this regards, the value of Comparative Fit Index (CFI) is 0.886 and it is also close to one. Furthermore, the result above shows that the value of Root Mean Square Error of Approximation (RMSEA) is 0.121 is close to zero (Hair et al., 2010). Moreover, the Average Variance Expositor is 0.314. As a consequence, the next step is to examine the indirect relationship between talent management and organization performance with the existing of work life balance. So, in order to make sure that the work life balance plays the role of mediating the following conditions must be meeting:

The significant value between organization performance and talent management should become insignificant with the presence of work life balance. The impact value of talent management on organization performance should be decreased after taking into account the work life balance. Most important thing (AVE) which represents the value of $\mathrm{R}^{2}$ should be increased after taking into consideration the work life balance. Therefore, if the above mentioned conditions achieved, the work life balance plays the role of mediators.

Table 14. Indirect effect summary

\begin{tabular}{|c|c|c|c|c|c|c|c|c|c|c|c|}
\hline & $\mathrm{Chi}^{2}$ & $\mathrm{Chi}^{2} / \mathrm{df}$ & GFI & CFI & RMSEA & SIG & DIRECT IMPACT & INDIRECT IMPACT & Sig & C.R & AVE \\
\hline TM-OP & 70.571 & 2.94 & 0.937 & 0.733 & 0.088 & 0.00 & 0.509 & 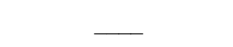 & 0.00 & 4.870 & \\
\hline TM-WLB & & & & & & & $\ldots$ & 0.423 & 0.00 & 5.382 & 0.482 \\
\hline WLB-OP & & & & & & & $\bar{L}$ & 0.380 & 0.00 & 4.413 & \\
\hline
\end{tabular}

The results of the above table show that the direct impact of talent management on the organization performance 0.509 in the presence of work life balance is lower than in the absence of the work life balance and the significant value 0.000 significant at $(\alpha \leq 0.05)$. This indicates that the work life balance plays the role of partial mediating. Also, the above results shows that the direct impact of talent management on work life balance 0.423 is significant at $(\alpha \leq 0.05)$ because the sig-value 0.000 . This indicates that talent management has an indirect effect on work life balance. Moreover, the result above shows that work life balance has a direct impact on organization performance at $(\alpha \leq 0.05)$ and the value of direct impact is 0.380 . Additionally, the value of AVE increased in the presence of the mediator. Therefore, the effect of the talent management on organization performance has been increased in the presence of Work Life Balance. Accordingly, we reject the null hypothesis and the alternative accepted (H6).

Furthermore, the results in the above reveal that the value of $\mathrm{Chi}^{2}$ is 70.571 and it is significant at $(\alpha \leq 0.05)$. Also, the Minimum Discrepancy value $\left(\mathrm{Chi}^{2} / \mathrm{df}\right)$ is 2.940 which indicate that the harmonization level is good; where (Arbuckle, 2008) stated that the harmonization level range 1 to 5. Additionally, the Goodness of Fit Index (GFI) which represent the harmonization of quality is 0.937 and this value is close to one (Full compatibility). In this regards, the value of Comparative Fit Index (CFI) is 0.733 and it is also close to one. Furthermore, the result above shows that the value of Root Mean Square Error of Approximation (RMSEA) is 0.088 is close to zero (Hair et al., 2010, 116).

\subsubsection{Seventh Main Hypothesis}

To examine the indirect relationship between talent management and organization performance with existing motivational drivers of employee engagement as mediating variable; the path analysis for mediation will be used. Accordingly, to examine the role of mediator, the following two steps have been adopted as below:

The first step is to examine the direct impact of talent management on organization performance in order to show the value of impact as well as the sig-value. 
Table 15. Direct effect summary

\begin{tabular}{lllllllllll}
\hline $\begin{array}{l}\text { TM- } \\
\text { OP }\end{array}$ & Chi $^{2}$ & Chi $^{2} / \mathrm{df}$ & GFI & CFI & $\begin{array}{l}\text { RMSE } \\
\text { A }\end{array}$ & SIG & DIRECT IMPACT & Sig & C.R & AVE \\
\cline { 2 - 11 } & 18.49 & 4.623 & 0.97 & 0.88 & 0.121 & 0.00 & 0.512 & 0.00 & 8.53 & 0.31 \\
& 4 & & 0 & 6 & & 1 & & 0 & 8 & 4 \\
\hline
\end{tabular}

The results of the above table show that the value of direct effect is 0.512 and it is significant at $(\alpha \leq 0.05)$. This implies that the talent management has a significant effect on the organization performance. Furthermore, the results in the above reveal that the value of $\mathrm{Chi}^{2}$ is 18.494 and it is significant at $(\alpha \leq 0.05)$. Also, the Minimum Discrepancy value ( $\mathrm{Chi}^{2}$ / df) is 4.623 which indicate that the harmonization level is good; where (Arbuckle, 2008) stated that the harmonization level range 1 to 5. Additionally, the Goodness of Fit Index (GFI) which represents the harmonization of quality is 0.970 and this value is close to one (full compatibility). In this regards, the value of Comparative Fit Index (CFI) is 0.886 and it is also close to one. Furthermore, the result above shows that the value of Root Mean Square Error of Approximation (RMSEA) is 0.121 is close to zero (Hair et al., 2010). Moreover, the Average Variance Expositor is 0.314.

As a consequence, the next step is to examine the indirect relationship between talent management and organization performance with the existing of motivational drivers of employee engagement. So, in order to make sure that the motivational drivers of employee engagement plays the role of mediating the mentioned before conditions on the sixth hypothesis must be met. Therefore, if the mentioned conditions achieved, the motivational drivers of employee engagement play the role of mediators.

Table 16. Indirect effect summary

\begin{tabular}{|c|c|c|c|c|c|c|c|c|c|c|c|}
\hline & $\mathrm{Chi}^{2}$ & chi2/df & GFI & CFI & RMSEA & SIG & DIRECT IMPACT & INDIRECT IMPACT & Sig & C.R & \\
\hline & & & & & & & & & & & AVE \\
\hline TM-OP & 70.430 & 2.934 & 0.937 & 0.768 & 0.088 & 0.000 & 0.068 & - & 0.324 & 0.985 & 0.343 \\
\hline TM-MDEE & & & & & & & 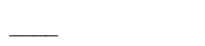 & 0.806 & 0.000 & 12.74 & \\
\hline MDEE-OP & & & & & & & & 0.505 & 0.000 & 6.534 & \\
\hline
\end{tabular}

The results of the above table show that the direct impact of talent management on the organization performance 0.068 in the presence of motivational drivers of employee engagement is lower than in the absence of the motivational drivers of employee engagement and the significant value 0.324 it is not significant at $\quad(\alpha \leq 0.05)$. This indicates that the motivational drivers of employee engagement play the role of mediating. Also, the above results shows that the direct impact of talent management on motivational drivers of employee engagement 12.741 is significant at $(\alpha \leq 0.05)$ because the sig-value 0.000 . This indicates that talent management has a direct effect on motivational drivers of employee engagement. Moreover, the result above shows that motivational drivers of employee engagement has a direct impact on organization performance at $(\alpha \leq 0.05)$ and the value of direct impact is 6.534. Additionally, the value of AVE increased in the presence of the mediator. Therefore, the effect of the talent management on organization performance has been increased in the presence of motivational drivers of employee engagement. Accordingly, we reject the null hypothesis and the alternative accepted (H7).

Furthermore, the results in the above reveal that the value of $\mathrm{Chi}^{2}$ is 70.430 and it is not significant at $(\alpha \leq 0.05)$. Also, the Minimum Discrepancy value ( $\mathrm{Chi}^{2} / \mathrm{df}$ ) is 2.934 which indicate that the harmonization level is good; where (Arbuckle, 2008) stated that the harmonization level range 1 to 5. Additionally, the Goodness of Fit Index (GFI) which represents the harmonization of quality is 0.937 and this value is close to one (Full compatibility). In this regards, the value of Comparative Fit Index (CFI) is 0.768 and it is also close to one. Furthermore, the result above shows that the value of Root Mean Square Error of Approximation (RMSEA) is 0.088 is close to zero (Hair et al., 2010, 116).

\section{Discussion and Conclusions}

\subsection{Discussion}

The main purpose of this study is to examine the mediating role of work life balance and motivational drivers of employee engagement on the relationship between talent management and organization performance. Therefore, based on the study statistical results, the study found that there is a positive relationship between talent management (talent attraction, talent development and talent retention) and organization performance in the 
telecommunication and information technology sector in Jordan. These results are consistent with (Bat \& Yalcin, 2015). This indicates that the correct adoption of talent management programs through acquiring, developing and retaining qualified employees to accomplish the company goals led to increase the organization performance whether its' human resources, operational and financial outcomes. Additionally, the successful application of talent management in the telecommunication and information technology sector will improve and enhance the quality of company procedures. Such as, work efficiency, productivity and effectiveness. Additionally, on the one hand, the right adoption of talent management will improve the organization performance with regard to the financial status. Moreover, the right application of talent management will improve the employees' potentials and capabilities as well as their skill which they are considered as a vital part of the company success (Jiang et al, 2012). On the other hand, effective talent management practices contribute in encouraging and motivating the company workers to perform their work effectively and efficiently (Johnson, 2004); which in turn lead to improve the organization performance (Obeidat et al., 2013).

Also, the study found that there is a positive relationship between talent management (talent attraction, talent development and talent retention) and work life balance in the telecommunication and information technology sector in Jordan. These results are consistent with (Kossek et al., 2014; Parakandi \& Behery, 2016). This indicates that the success implementation of talent management in the telecommunication and information technology sector in Jordan, which is shown through changing the traditional functions and responsibilities of the human resources department and discovering their skills and needs through their career path in the organization helps the employees to have capabilities that allow them to balance between their work life and their own private life; through giving them more chances and degree of independence to control their work (Mahanta, 2015).

This study also found that there is a positive relationship between talent management (talent attraction, talent development and talent retention) and motivational drivers of employee engagement. These results are consistent with (Jauhari et al., 2013). This indicates that the correct adoption of talent management responsibilities (acquiring, developing and retaining talented workers) will increase the degree of employee involvement in taking the right decisions that might have a positive influence on their work performance. Additionally, the successful application of talent management responsibilities will open the doors for a learning organization which allow the employees to develop their characteristics that motivate them to improve their skills and abilities as well as creating the opportunities for growth. Furthermore, talent management contributes in increasing the level of equality among the employees as well as the human resources department practices with regard to fair treatment. Moreover, talent management supports the concept of right leadership which includes motivating, appreciating, guiding, inspiring and influencing the employees to achieve their tasks in an effective manner (see e.g. AlHarrasi \& AL-Lozi, 2015; AlHarrasi et al., 2016; AL-Syaidh et al., 2016; Darawsheh et al., 2016; Alkandari et al., 2017; Khalayleh et al., 2017; Abualoush et al., 2018a, 2018b; Al-dalahmeh et al., 2018; Masa'deh, et al., 2018).

This study found that there is a positive relationship between organizational performance and work / life balance (employment and working hours, Family care, fringe benefits and organizational culture reinforcement). These results are consistent with (Benito-Osorio et al., 2014). This indicates that the increases of work life balance level contribute in increasing the outcome of human resources, operational and financial. Precisely speaking, work life balance as a crucial concept for workers needs in the telecommunication and information technology sector in Jordan, considered as a vital part in supporting the human capital and motivation of employees. Since, work life balance can play a significant role in the company success through raising the capabilities and skills of workers to achieve their goals and by encouraging them to accomplish the company tasks effectively; especially when the employees feel that the equation between their personal life and work life are balanced.

Moreover, the study found a positive relationship between organization performance and motivational drivers of employee engagement (decision making authority, opportunities for growth and development, fair treatment and leadership). These results are consistent with (Bedarkar \& Pandita, 2013). This implies that telecommunication and information technology sector in Jordan consider their performance, whether it financial, operational or human resources as one of the most important priorities in their life cycle. Therefore, these results indicate that this type of companies highly focused on their performance through concentrating on many factors that significantly increases their employees' engagement. Such as, involving their workers in decision making and opening the doors of opportunities that maintain the development and implementing the right characteristics of leadership and fair treatment.

The study found that work life balance partially mediating the relationship between talent management and organization performance. This implies that the average variance explained in the presence of work life balance is higher than in the absence of it. In other words, we can conclude that work life balance clarifies the relationship between talent management and organization performance and work life balance is the function of the relationship 
between talent management and organization performance. Therefore, this implies that when the telecommunication and information technology sector in Jordan; taking into consideration the worker's needs, increasing the level of management consideration of human touch and introducing them lots of facilities that help them to balance their personal and work life, it helps the company's management to keep their progress to improve the company performance.

Finally, the study found motivational drivers of employee engagement mediating the relationship between talent management and organization performance. This indicates that the average variance explained in the presence of motivational driver of employee engagement is higher than in the absence of it. However, the study results found that motivational drivers of employee engagement totally converted the directed relationship between talent management and organization performance to indirect relationship and this indirect relationship became stronger when the motivational drivers of employee engagement considered as a function of the talent management. Therefore, this implies that the existence of motivational driver of employee engagement (decision making authority, opportunity for growth and development, fair treatment and leadership) along with talent management will boost the organization performance as well as the company progress.

\subsection{Recommendation}

Based on the study results, the researchers suggest the following recommendation that might be helpful to the telecommunication and information sector in Jordan with regard to the study concern:

The researchers recommend the telecommunication and information sector in Jordan to improve various methods and techniques of recruitment in order to gain more talented individuals to be part in their company. Since, talented workers considered as one of the most significant assets of the company success.

The telecommunication and information sector in Jordan should shed the light on the progress, assignments that help the employees to grow. Such as, special projects, cross-functional assignments and customer interactions. Because assignments might raise the talent potentials of employees, which in turn led to enhance the level of performance, as a consequence, those companies should focus on retaining high-potential employees in order to gain rewards from them in the future wither rewards related to work efforts or task achievements.

Talented employees spent the majority of their time in training programs as well as they are more likely to participate in the development projects to improve their talent skills. However, the companies also should aware them to devote some of their valuable time for their personal life needs in order to maintain the equation of work and personal life balanced. Accordingly, this will improve the productivity of employees; which in turn will improve the company performance and their social responsibilities.

Even the work life balance considered as one of the most significant feature that contribute satisfaction for employees; it must be widely recommended for all individual workers in the company to improve the future performance of the company.

Development is the road map to success. Therefore, the telecommunication and information technology sector should offer many opportunities for their employees, based on their performance, to grow and to have a career path. As a consequence, employees will give more efforts to perform their tasks efficiently and effectively.

The researchers suggest the future research to take into account other sectors for generalizability purposes.

According to the researchers best of knowledge, there are many growing evidences of the importance of work life balance in companies; however, the academic researchers didn't give it a high concern, especially in Jordan and Middle East countries.

Also, researchers called for more research on the enabling factors of applying electronic services (e.g. Masa'deh, et al., 2008, 2013a, 2013b; Karajeh \& Maqableh, 2014; Maqableh \& Karajeh, 2014; Al-Dmour et al., 2015; Almajali \& Maqableh, 2015; Kateb et al., 2015; Maqableh et al., 2015; Masa'deh, 2016; Tarhini et al., 2015; 2016, 2017a, 2017b; Almajali \& Al-Dmour, 2016; Almajali et al., 2016; Alenezi et al., 2017; Aldmour et al., 2017; Khwaldeh et al., 2017; Mikkawi \&Al-Lozi, 2017; Obeidat et al., 2017; Yassien \& Mufleh, 2017; Tarhini et al., 2018; Al-Dmour et al., 2019), hence, future research is vital to explore in new electronic venues the relationship between talent management, work life balance, motivational drivers of employee engagement and organization performance.

\subsection{Limitations of the Study}

Several limitations should be noted in the study. One of the limitations is the sample size of 250 respondents which prevent the full representation of the market. Moreover, academic research and implications of work life balance is in shortage in Jordan and Middle East. Therefore, the researchers are highly recommended the future researches 
to focus on this variable. Since, this variable holds many benefits for organization future performance and societies. Third limitation, this study focus is limited to telecommunication and information technology sector and questioned only the employees of the big three companies (Zain, Orange and Umniah) due to the researchers time limitation. Thus, there may be difficulty in applying the study results to other sectors in Jordan.

\section{References}

Abualoush, S. H., Obeidat, A. M., Tarhini, A., Masa'deh, R., \& Al-Badi, A. (2018b). The role of employees' empowerment as an intermediary variable between knowledge management and information systems on employees' performance. VINE Journal of Information and Knowledge Management Systems, 48(2), 217237.

Abualoush, S., Bataineh, K., \& Alrowwad, A. (2018a). The role of knowledge management process and intellectual capital as intermediary variables between knowledge management infrastructure and organization performance. Interdisciplinary Journal of Information, Knowledge, and Management, 13, 279-309.

Akanji, B., Mordi, C., \& Ojo, S. (2015). Reviewing gaps in work-life research and prospecting conceptual advancement. Petroleum-Gas University of Ploiesti bulletin, Technical Series, 67(3).

Al-dalahmeh, M., Khalaf, R., \& Obeidat, B. (2018). The effect of employee engagement on organizational performance via the mediating role of job satisfaction: The case of IT employees in Jordanian banking sector. Modern Applied Science, 12(6), 17-43.

Al-Dmour, R., Al Haj Dawood, E., Al-Dmour, H., \& Masa'deh, R. (2019). The effect of customer lifestyle patterns on the use of mobile banking applications in Jordan. Int. J. Electronic Marketing and Retailing, Forthcoming.

Aldmour, R., Masa'deh, R., \& Obeidat, B. (2017). Factors influencing the adoption and implementation of HRIS applications: Are they similar. International Journal of Business Innovation and Research, 14(2), 139-167.

Al-Dmour, R., Obeidat, B., \& Almajali, D. (2015). The practice of HRIS applications in business organizations in Jordan: An empirical study. 4th Scientific \& Research Conference on New Trends in Business, Management and Social Sciences (COES\&RJ-TK15/1).

Alenezi, H., Tarhini, A., Alalwan, A., \& Al-Qirim, N. (2017). Factors affecting the adoption of e-government in Kuwait: A qualitative study. Electronic Journal of e-Government, 15(2), 84-102.

AlHarrasi, J., \& AL-Lozi, M. (2015). The role of innovation management and technological innovation on organizational effectiveness. 4th Scientific \& Research Conference on New Trends in Business, Management and Social Sciences (COES\&RJ-TK15/1), Istanbul, Turkey.

AlHrassi, J., Al-Lozi, M., \& Irtaimeh, H. (2016). The impact of management innovation and technological innovation on organizational effectiveness: An empirical study from managerial staff perspective in Sultan Qaboos University. Journal of Social Sciences (COES\&RJ-JSS), 5(3), 309-339.

Alkandari, A., Masa'deh, R., \& Al-Lozi, M. (2017). Knowledge management and its role on organizational crisis management: A literature review. Journal of Social Sciences (COES\&RJ-JSS), 6(4), 833-850.

Almajali, D., \& Al-Dmour, R. (2016). The role of information technology in motivating students to accept elearning adoption in universities: A case study in Jordanian universities. Journal of Business \& Management (COES\&RJ-JBM), 4(1), 36-46.

Almajali, D., \& Maqableh, M. (2015). Assessing the digital divide status of the Jordanian telecentre. International Journal of Communications, Network and System Sciences, 8(11), 428-439.

Almajali, D., Masa'deh, R., \& Al-Lozi, M. (2016). Determinants of the actual use of e-learning systems: An empirical study on Zarqa University in Jordan. Journal of Social Sciences (COES\&RJ-JSS), 5(2), 172-200.

Alnsour, M., Abu Tayeh, B., \& Alzyadat, M. (2014). Using SERVQUAL to assess the quality of service provided by Jordanian telecommunications sector. International Journal of Commerce and Management, 24(3), 209218.

AL-Syaidh, N., Al-Lozi, M., \& AlHarrasi, J. (2016). Transformational leadership and its role on the effectiveness of employees' behavior: A theoretical study. Journal of Business \& Management (COES\&RJ-JBM), 4(1), 1435 .

Arbuckle, J. L. (2008). Amos 7.0 users guide, Springhouse, PA: Amos Development Corporation.

Bat, M., \& Yalcin, M. (2015). An evaluation of talent management from an organizational perspective: The case of vodafone. Global Media Journal: Turkish Edition, 6(11). 
Bedarkar, M., \& Pandita, D. (2014). A study on the drivers of employee engagement impacting employee performance. Procedia-Social and Behavioral Sciences, 133, 106-115.

Benito-Osorio, D., Muñoz-Aguado, L., \& Villar, C. (2014). The impact of family and work-life balance policies on the performance of Spanish listed companies.M@n@gement, 17(4),214-236.

Bhatnagar, J. (2007). Talent management strategy of employee engagement in Indian ITES employees: Key to retention. Employee Relations, 29(6), 640-663.

Bhuvanaiah, T., \& Raya, R. P. (2015). Mechanism of improved performance: Intrinsic motivation and employee engagement. SCMS Journal of Indian Management, 12(4), 92.

Canavan, D., Sharkey Scott, P., \& Mangematin, V. (2013). Creative professional service firms: Aligning strategy and talent. Journal of Business Strategy, 34(3), 24-32.

Casper, W.J., Eby, L.T., Bordeaux, C., Lockwood, A., \& Lambert, D. (2007). A review of research methods in IO/OB work-family research. Journal of Applied Psychology, 92(1), 28.

Coff, R., \& Kryscynski, D. (2011). Invited editorial: Drilling for micro-foundations of human capital-based competitive advantages. Journal of Management, 37(5), 1429-1443.

Darawsheh, S., ALshaar, A., \& AL-Lozi, M. (2016). The degree of heads of departments at the University of Dammam to practice transformational leadership style from the point of view of the faculty members. Journal of Social Sciences (COES\&RJ-JSS), 5(1), 56-79.

Garavan, T. N., Carbery, R., \& Rock, A. (2012). Mapping talent development: Definition, scope and architecture. European Journal of Training and Development, 36(1), 5-24.

Gołaszewska-Kaczan, U. (2015). Actions for promoting work-life balance as an element of corporate social responsibility. Prace Naukowe Uniwersytetu Ekonomicznego we Wroctawiu, 387, 54-65.

Gözükara, İ., \& Şimşek, O. F. (2015). Linking transformational leadership to work engagement and the mediator effect of job autonomy: A study in a Turkish private non-profit university. Procedia-Social and Behavioral Sciences, 195, 963-971.

Hair, J. F., Black, W. C., Babin, B. J., Anderson, R. E., \& Tatham, R. L. (2010). Multivariate data analysis, 7th edition, New York: Macmillion Publishing Company.

Hajir, J. A., Obeidat, B. Y., \& Al-Dalahmeh, M. A. (2015). The role of knowledge management infrastructure in enhancing innovation at mobile telecommunication companies in Jordan. European Journal of Social Sciences, 50(3), 313-330.

Helmle, J., Botero, I., \& Seibold, D. (2014). Factors that influence perceptions of work-life balance in owners of copreneurial firms. Journal of Family Business Management, 4(2), 110-132.

Idrovo Carlier, S., Leon Llorente, C., \& Grau Grau, M. (2012). Comparing work-life balance in Spanish and LatinAmerican countries. European Journal of Training and Development, 36(2/3), 286-307.

Jauhari, V., Sehgal, R., \& Sehgal, P. (2013). Talent management and employee engagement: Insights from Infotech enterprises LTD. Journal of Services Research, 13(1), 161.

Jiang, K., Lepak, D. P., Hu, J., \& Baer, J. C. (2012). How does human resource management influence organizational outcomes? A meta-analytic investigation of mediating mechanisms. Academy of Management Journal, 55(6), 1264-1294.

Johnson, M. (2004). The new rules of engagement, CIPD Publishing.

Karajeh, H., \& Maqableh, M. (2014). Security of cloud computing environment. The 23rd IBIMA Conference on Vision 2020: Sustainable Growth, Economic Development, and Global Competitiveness, USA, 2202-2215.

Kateb, M., Swies, R., Obeidat, B., \& Maqableh, M. (2015). An investigation on the critical factors of information system implementation in Jordanian information technology companies. European Journal of Business and Management, 7(36), 11-28.

Khalayleh, W., Masa'deh, R., \& Al-Lozi, M. (2017). Administrative empowerment and its role on the work teams Performance: A literature review. Journal of Social Sciences (COES\&RJ-JSS), 6(4), 851-868.

Khwaldeh, S., Al-Hadid, I., Masa'deh, R., \& Alrowwad, A. (2017). The association between e-services web portals information quality and ICT competence in the Jordanian universities. Asian Social Science, 13(3), 156-169. 
Kossek, E. E., Thompson, R. J., \& Lautsch, B. A. (2015). Balanced workplace flexibility. California Management Review, 57(4), 5-25.

Mahanta, M. (2015). Exploring the relationship between emotional intelligence and work-life balance in the service industry. IUP Journal of Organizational Behavior, 14(2).

Maqableh, M., \& Karajeh, H. (2014). Job scheduling for cloud computing using neural networks. Communications and Network, 6(3), 191-200.

Maqableh, M., Rajab, L., Quteshat, W., Khatib, T., \& Karajeh, H. (2015). The impact of social media networks websites usage on students' academic performance. Communications and Network, 7(4), 159-171.

Masa'deh, R. (2016). The role of knowledge management infrastructure in enhancing job satisfaction at Aqaba five star hotels in Jordan. Communications and Network, 8(4), 219-240.

Masa'deh, R., Alrowwad, A., Alkhalafat, F., Obeidat, O., \& Abualoush, S. (2018). The role of corporate social responsibility in enhancing firm performance from the perspective of IT employees in Jordanian banking sector: The mediating effect of transformational leadership. Modern Applied Science, 12(7), 1-26.

Masa'deh, R., Gharaibeh, A., Maqableh, M., \& Karajeh, H. (2013a). An empirical study of antecedents and outcomes of knowledge sharing capability in Jordanian telecommunication firms: A structural equation modeling approach. Life Science Journal, 10(4), 2284-2296.

Masa'deh, R., Hunaiti, Z., \& Bani Yaseen, A. (2008). An integrative model linking IT-business strategic alignment and firm performance: The mediating role of pursuing innovation and knowledge management strategies. Communications of the International Business Information Management Association (IBIMA) Journal.

Masa'deh, R., Obeidat, B., Zyod, D., \& Gharaibeh, A. (2015). The associations among transformational leadership, transactional leadership, knowledge sharing, job performance, and firm performance: A theoretical model. Journal of Social Sciences (COES\&RJ-JSS), 4(2), 848-866.

Masa'deh, R., Shannak, R., \& Maqableh, M. (2013b). A structural equation modeling approach for determining antecedents and outcomes of students' attitude toward mobile commerce adoption. Life Science Journal, 10(4), 2321-2333.

Mathew, A. (2015). Talent management practices in select organizations in India. Global Business Review, 16(1), 137-150.

Mikkawi, B., \& Al-Lozi, M. (2017). The impact of knowledge management infrastructure on academic staff effectiveness: An empirical study at The University of Jordan. Jordan Journal of Business Administration, 13(1), 95-127.

Obeidat, B., El-Rimawi, S., Maqableh, M., \& Al-Jarrah, I. (2013). Evaluating the profitability of the Islamic banks in Jordan. European Journal of Economics, Finance and Administrative Sciences, 56, 27-36.

Obeidat, B., Tarhini, A., \& Aqqad, N. (2017). The impact of intellectual capital on innovation via the mediating role of knowledge management: A structural equation modeling approach. International Journal of Knowledge Management Studies, 8(3/4), 273-298.

Pallant, J. (2005). SPSS survival manual: A step by step guide to data analysis using SPSS for windows (version 12). 2nd ed., Maidenhead: Open University Press.

Parakandi, M., \& Behery, M. (2016). Sustainable human resources: Examining the status of organizational worklife balance practices in the United Arab Emirates. Renewable and Sustainable Energy Reviews, 55, 13701379.

Pickett, L. (2005). Optimising human capital: Measuring what really matters. Industrial and Commercial Training, 37(6), 299-303.

Robinson, D., Perryman, S., \& Hayday, S. (2004). The drivers of employee engagement. IES Research Network.

Sekaran, U., \& Bougie, R. J. (2013). Research methods for business: A skill building approach (6th ed.). United Kingdom: Wiley \& Sons.

Shafei, I., Tabaa, H., \& Tabaa, H. (2016). Factors affecting customer loyalty for mobile telecommunication industry. EuroMed Journal of Business, 11(3), 347-361.

Slavković, M., Babić, V., \& Stojanović-Aleksić, V. (2015). Talent management: Opportunities and limitations for Serbian organizations. Teme: Casopis za Društvene Nauke, 39(2). 
Tarhini, A., Alalwan, A., Al-Qirim, N., \& Algharabat, R. (2018). An analysis of the factors influencing the adoption of online shopping. International Journal of Technology Diffusion (IJTD), 9(3), 68-87.

Tarhini, A., Al-Badi, A., Almajali, M., \& Alrabayaah, S. (2017a). Factors influencing employees' intention to use cloud computing. Journal of Management and Strategy, 8(2), 47.

Tarhini, A., Al-Busaidi, K., Bany Mohammed, A., \& Maqableh, M. (2017b). Factors influencing students' adoption of e-learning: A structural equation modeling approach. Journal of International Education in Business, 10(2), 164-182.

Tarhini, A., Bany Mohammed, A., \& Maqableh, M. (2016). Modeling factors affecting student's usage behaviour of e-learning systems in Lebanon. International Journal of Business and Management, 11(2), 299.

Tarhini, A., Mgbemena, C., \& Trab, M. S. A. (2015). User adoption of online banking in Nigeria: A qualitative study. Journal of Internet Banking and Commerce, 20(3), 1-8.

Thunnissen, M. (2016). Talent management: For what, how and how well? An empirical exploration of talent management in practice. Employee Relations, 38(1), 57-72.

Yassien, E., \& Mufleh, M. (2017). The impact of ERP system's usability on enterprise resource planning project implementation success via the mediating role of user satisfaction. Journal of Management Research, 9(3), 49-71.

\section{Copyrights}

Copyright for this article is retained by the author(s), with first publication rights granted to the journal.

This is an open-access article distributed under the terms and conditions of the Creative Commons Attribution license (http://creativecommons.org/licenses/by/4.0/). 